\title{
EXPERIMENTAL STUDY ON A SOLAR-HEATED BIOGAS DIGESTER USING SHALLOW SOLAR POND IN COLD CLIMATE
}

\author{
Abd El-Wahab M.K. ${ }^{1}$ \\ Hassan M.M.A ${ }^{2}$ \\ Tawfik M.A. ${ }^{2}$ \\ Abd Allah W. $\mathbf{E}^{3}$
}

\begin{abstract}
In northern Egypt, the ambient temperature almost below $20^{\circ} \mathrm{C}$ during winter months, which is insufficient for the anaerobic digestion (AD) and affecting negatively the biogas yield, especially for the floating dome digester(Indian model) due to the heat losses through the gas holder. Since the slurry temperature is a crucial factor for the AD rate, this investigation aims to heat a concrete pre-constructed floating dome biogas digester (Family-scale digester) during winter season for enhancing the fermentation rate by utilizing the extracted heat of integrated shallow solar pond (SSP) using dairy cattle dung comparing to a previous work of un-heated digester. The solar-heated digester was evaluated under the same operating conditions of the un-heated digester except the slurry temperature and similar values of both the solar radiation intensity and ambient temperature during 30 days without feeding as a digestion time taking into consideration the slurry temperature, $\mathrm{pH}$, daily, cumulative ( $\left.\mathrm{m}^{3} / \mathrm{month}\right)$ and specific $\left(\mathrm{m}^{3} / \mathrm{kg}_{\mathrm{vS}}\right)$ biogas yield as well as the total net gained energy. The obtained results revealed that, the average slurry temperature of the solar-heated biogas digester system increased by $12.3^{\circ} \mathrm{C}$ which led to increase the average daily, cumulative and specific biogas yield by about $129 \%$ higher than the unheated digester with average methane content of $70 \%$ and total net gained energy of $553.1 \mathrm{MJ} / \mathrm{month}$.
\end{abstract}

Keywords: anaerobic digestion, winter season, shallow solar pond, cattle dung, solar heated-biogas digester, biogas yield

\footnotetext{
${ }^{1}$ Professor Emeritus, Agric. Eng. Dept., Fac. of Agric., Zagazig Univ., Egypt. ${ }^{2}$ Assistant. Prof., Agric. Eng. Dep., Fac. of Agric., Zagazig Univ., Egypt.

${ }^{3}$ Lecturer, Agric. Eng. Dept., Fac. of Agric., Zagazig Univ., Egypt.
} 


\section{INTRODUCTION}

$\mathrm{E}$ gypt has 4.2 and 4.95 million head of buffaloes and cattle, respectively (FAO, 2013), thus the anaerobic digestion (AD) process of animal dung for producing biogas is very potential. The growth and activity of anaerobic microorganisms is highly affected by many factors such as the presence of oxygen, $\mathrm{pH}$ of slurry, temperature, type of feedstock, stirring as well as the amount of inhibitors (Al Seadi et al.,2008), which can influence the yield and composition of biogas. AD is affected by temperature (Chae et al., 2006) so; temperature is considered a crucial factor for $\mathrm{AD}$ as it determines the period and rate of anaerobic degradation process particularly at the hydrolysis and methanogenesis phases. Nijaguna (2009) classified the AD into three categories according to the temperature which are called the psychrophilic $\left(<20^{\circ} \mathrm{C}\right)$, mesophilic $\left(25\right.$ to $\left.37^{\circ} \mathrm{C}\right)$ and thermophilic (45 to $65^{\circ} \mathrm{C}$ ), where the $\mathrm{AD}$ essentially stops below $10{ }^{\circ} \mathrm{C}$. Gupta et al. (1988) concluded that, increasing the slurry temperature of the bioreactor using solar collector from $20{ }^{\circ} \mathrm{C}$ to $35{ }^{\circ} \mathrm{C}$ (mesophilic digestion) significantly improved biogas yield for both the dairy manure digestion and codigestion (manure+ food wastes), but by further increase in temperature to $50{ }^{\circ} \mathrm{C}$ resulting in less improvement in biogas production. Due to the initial installation and operation costs of thermophilic digestion are significantly higher than those of mesophilic digestion, thus the mesophilic digestion is more applicable in developing countries (Wang et al., 2016). On the other hand, at temperature below $15{ }^{\circ} \mathrm{C}$, the $\mathrm{AD}$ requires more than 75 days as retention time (Zeeman and Lettinga, 1999) because the psychrophilic AD in cold climate needs high retention time or large volume of digester. The large volume of the anaerobic digester means high cost of the system construction (Santosh et al., 2004). In northern Egypt and Delta, the average temperature is almost below $20^{\circ} \mathrm{C}$ (psychrophilic range) during winter season; therefore the rate of $\mathrm{AD}$ will be in a lower level due to the inhibition of the mesophilic metabolism microbes which makes the biogas a less reliable energy resource. It is obvious that, the $\mathrm{AD}$ is affected negatively by the cold climate, thus some early options for digester-warming technology were investigated which included the charcoal coating of ground around the 
digester (Anand and Singh,1993), electric heating, oil, biogas heating (El-Mashad et al., 2004); coal-fired boiler heating (Shi et al.,2013); biogas engine-driven heat pump air conditioner (Xu et al.,2010) ; new type of solar heat pipe (Jiao et al.,2016) and the hot gas (Kitamura $\boldsymbol{e t}$ al.,2007). The impact of the mentioned heating technologies was very effective, but the high energy consumption means high costs (Dong and Lu, 2013). The solar assisted biogas systems including solar collectors (Zhu et al., 2013); with temperature sensors and controller (Li et al., 2014), evacuated solar thermal collectors (Zhong et al., 2015) and the solar salt pond were studied (Subramanyam, 1989). These heating systems are expensive, complex and still need to considerable repairing and maintenance. Also, the black-coated translucent plastic with the digester (Kumar and Bai, 2005); PVC greenhouse type structure over the gas holder (Bansal et al.,1985) and biogas plant assisted by solar greenhouse on the par with the conventional brick material (Kumar and Bai, 2008) were utilized to accelerate the AD. But these heating methods are somewhat efficient in cold regions due to the low solar radiation and ambient temperature (Chenglin et al., 2009). Utilizing clean energy to improve the fermentation temperature and maintain the efficiency of biogas production during winter is widely approbatory (Lu et al., 2014).This is can be considered an important target for improving the performance of any biogas production system. So, there is an urgent need to use an inexpensive and simple design solar heater to achieve this target. Regarding the novelty of this work, there is no previous investigation or literature about utilizing the shallow solar pond (SSP) as a solar heater for heating the biogas digester to maintain the $\mathrm{AD}$ temperature in the mesophilic range during cold periods. Basically, the SSP can be classified as a solar collector that can be used for collecting and storing heat (Ganesh and Arumugam, 2016). The SSP is capable of heating a large quantity of water to appreciable temperature and because of its simplicity in working, it holds out promise for one of the cheapest methods for harnessing solar energy (El-Sebaii,2005), so it can be considered as a low cost thermal collector compared to the flat plate and vacuum tube collectors. Hence, the main aim of this work is exploiting the solar energy for enhancing the biogas yield by the integration of SSP with a pre- 
constructing floating dome digester during winter season in northern Egypt.

\section{MATERIALS AND METHODS}

The practical experiments were carried out at the farm of Experimental and Agricultural Researches Centre, Faculty of Agriculture, Zagazig University, Zagazig city (Lat. $30^{\circ} 35^{\prime} \mathrm{N}$, Long. $31^{\circ} 31^{\prime} \mathrm{E}$ ), Egypt. In the present work, the performance evaluation of an integrated SSP with a pre-constructed concrete floating dome biogas digester (Indian model) was performed during a cold period started from January $13^{\text {th }}$ to $12^{\text {th }}$ February 2016 without feeding as a batch process comparing to the performance of the same digester without heating under the same operating conditions such as; the experiment's region, digestion time, feedstock type, $\mathrm{C} / \mathrm{N}$ ratio, total solid and the effective volume during the cold period started from December $11^{\text {th }} 2015$ to $11^{\text {th }}$ January 2016 according to (Abd allah et al., 2016).

\section{The experimental setup}

\subsection{The solar-heated biogas digester}

The solar-heated biogas digester consists mainly of: SSP, floating dome biogas digester and heating loop, as shown in Fig.1.

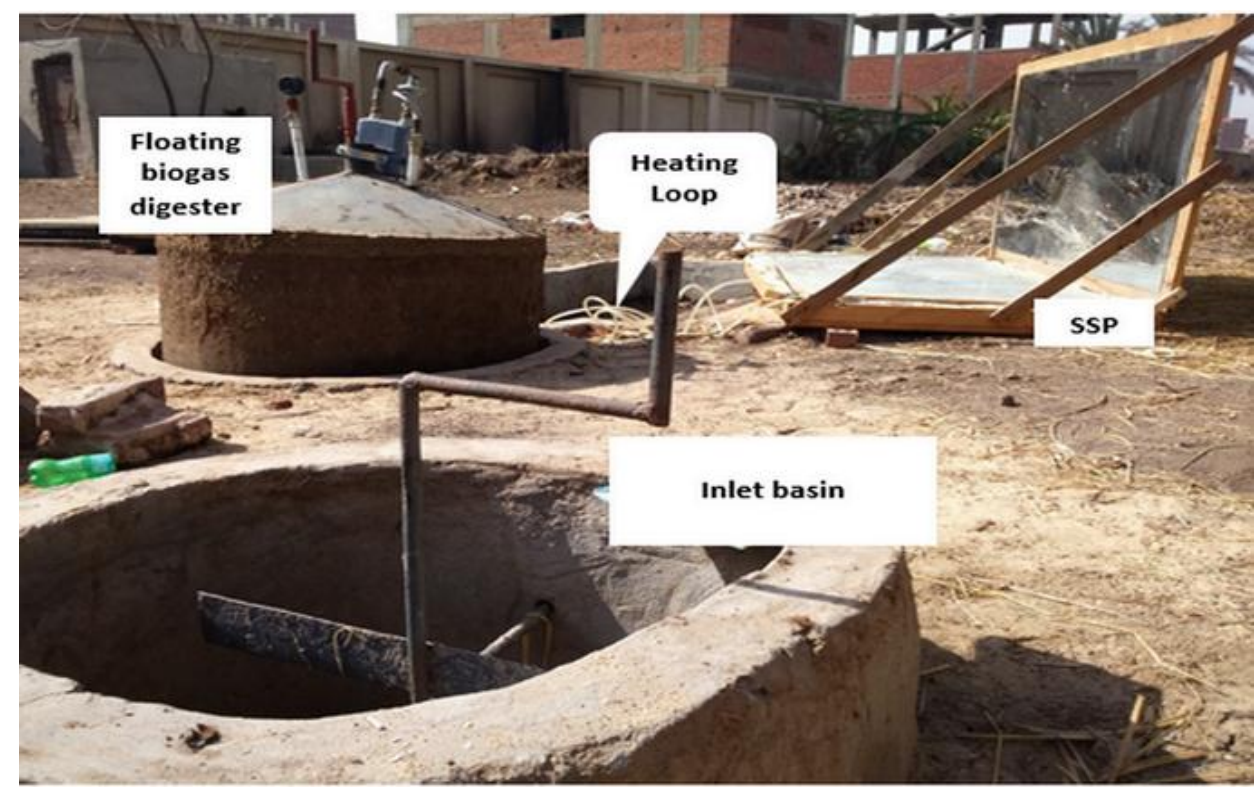

Fig. (1): The Experimental solar-heated biogas digester. 


\section{-The SSP:}

The SSP was designed and fabricated with a bottom surface area of $2 \mathrm{~m}^{2}$ with $3 \mathrm{~cm}$ in depth, glass wool thickness of $5 \mathrm{~cm}$ as thermal insulator provided with $90^{\circ}$ booster mirror according to the recommendations of (Abd Allah, 2016). For exploiting the collected solar heat by the SSP, a black painted serpentine heat exchanger ( $\mathrm{SHE}_{\mathrm{Pond}}$ ) that made of copper was welded to the upper surface of the pond absorber copper plate and separated with interval distance of $15 \mathrm{~cm}$, outer and inner pipes diameters equal to 1.5 and $0.79 \mathrm{~cm}$, respectively.

\section{-The Floating dome biogas digester:}

The constructed digester is a modified Indian digester model of KIVC that included the digestion chamber, gas holder, manual agitator, mixing and drying basins. To reduce the time, effort and cost for constructing the digester, a pre-constructed cylindrical reinforced concrete digestion chamber was used with volume of $3.68 \mathrm{~m}^{3}$ using dimensions of $3,1.25$ and $0.12 \mathrm{~m}$ for the height, internal diameter and walls thickness, respectively, with two orifices for the inlet and outlet slurry. The volume of digestion chamber and gas holder (Total volume) was $4.41 \mathrm{~m}^{3}$ while the effective digestion volume (the slurry height within the chamber was $2.75 \mathrm{~m}$ ) was $3.37 \mathrm{~m}^{3}$. This chamber provided with a robust metal pipe as gas holder guide with $5.08 \mathrm{~cm}$ in diameter. Moreover, the ground level was above about $20 \mathrm{~cm}$ from the outlet port to permit the digested solution to flow out naturally.

The gas holder made of iron sheet with $0.2 \mathrm{~cm}$ in thickness and $1.15 \mathrm{~m}$ in diameter with internal sloped blades to break down the scum. At the center of holder, an open ends iron pipe with $7.62 \mathrm{~cm}$ in diameter was fixed to help the holder to move vertically through the gas holder guide, whilst an iron pipe at the upper part of holder with $1.83 \mathrm{~cm}$ in diameter used to extract the biogas. A propelled agitator with $1.90 \mathrm{~cm}$ in diameter and $400 \mathrm{~cm}$ in length provided with two sets of pitched blades ( 3 blades per set) in the lower part of digestion chamber. The agitator diameter was $31.25 \mathrm{~cm}$ ( $25 \%$ of the digester internal diameter). The inlet basin was constructed with diameter of $70 \mathrm{~cm}$ and depth of $80 \mathrm{~cm}$ provided with a manual steel mixer and connected to the bottom of the digester by a 
PVC pipe with diameter of $15.24 \mathrm{~cm}$, while the outlet basin was constructed for receiving the digested slurry (the effluent).

-The solar heating loop:

The solar heating loop depends upon the continuous open-cycle flow mode to transfer the accumulated heat from the $\mathrm{SHE}_{\text {Pond }}$ in SSP to another serpentine heat exchanger ( $\mathrm{SHE}_{\text {Digester }}$ ) with similar specifications located at the bottom of digester by recirculating tap water with flow rate of $0.41 \mathrm{~L} / \mathrm{s}$ using centrifugal pump (90 watt), controlling valve, and hoses. The $\mathrm{SHE}_{\text {Digester }}$ was coiled vertically in the depth of digestion chamber as a cylindrical shape with dimensions of $80 \mathrm{~cm}$ in diameter and $180 \mathrm{~cm}$ in height from digester bottom with similar specifications of the $\mathrm{SHE}_{\text {Pond. }}$

\subsection{The feedstock}

Fresh dairy cattle dung was collected and analyzed for chemical and physical compositions such as; total solids, volatile solids, organic carbon, and total nitrogen, as shown in Table (1). The initial moisture content of manure was determined in three replicates by drying the samples in an oven furnace at temperature of $105^{\circ} \mathrm{C}$ for 24 hours. At the start of filling, slurry from active biogas digester (microbial starter) was used with volume equal about $5 \%$ of the effective volume of digester.

Table (1): Chemical and physical compositions of the fresh cattle dung and Initial slurry

\begin{tabular}{lll}
\hline Parameters & Fresh dung & Initial slurry* \\
\hline Moisture content, \% (M.C.) & 81.8 & 92 \\
Total solids, \% (TS) & 18.2 & 8 \\
Volatile solids, \% (VS) & 13.9 & 6.12 \\
VS, \% (from TS) & 76.42 & 75.6 \\
Ash, \% & 4.3 & 1.98 \\
Ash, \% (from TS) & 23.6 & 24.4 \\
Total organic carbon, \% (C) & 44.33 & 43.85 \\
Total Nitrogen, \% (N) & 1.75 & 1.85 \\
Carbon/Nitrogen (C/N ratio) & $25.3: 1$ & $23.7: 1$ \\
pH value & 7.5 & 7.41 \\
\hline * Slurry before digestion. & & \\
2. Measurem
\end{tabular}

\section{Measurements and determinations}


The Performance evaluation of the solar-heated biogas digester was based on the following indicators:

\subsection{The ambient and digester temperatures:}

The ambient temperature $\left({ }^{\circ} \mathrm{C}\right)$ was measured by using WatchDog weather station (Model: 900ET, USA), while temperatures of the biogas digester were measured using $8 \mathrm{~K}$-type thermocouple sensors that located every 30 $\mathrm{cm}$ from the digester bottom with measuring range of -100 to $1300^{\circ} \mathrm{C}$ and accuracy of $\left( \pm 0.1 \% \mathrm{rdg}+0.7^{\circ} \mathrm{C}\right)$. The thermocouple sensors were plugged to the multi-channels digital data logging thermometer (Model: TM747 DU 4-Channel, Taiwan).

\subsection{The total solids (TS) of slurry:}

The cattle dung was mixed with water to reach the recommended value of total solid (TS) content of $8 \%$ by using Eq. 3 :

$$
\begin{aligned}
& \text { (Volume of dung } \times \text { TS concentrat ion })_{\text {before dilution }}= \\
& \text { (Volume of dung and water Mixture } \times \text { TS concentrat ion })_{\text {after dilution }} \\
& V_{\text {dung }} \times T s_{1}=\left(V_{\text {water }}+V_{\text {dung }}\right) \times T s_{2} \\
& V_{\text {water }}=\frac{V_{\text {dung }}\left(T s_{1}-T s_{2}\right)}{T s_{2}}
\end{aligned}
$$

Where:

$\mathrm{V}_{\text {water }}$ :amount of added water to dilute the dung into slurry, $\mathrm{kg}$.

$\mathrm{V}_{\text {dung }}$ :amount of raw material added (fresh dung), $\mathrm{kg}$.

$\mathrm{Ts}_{1}$ : total solids of fresh dung, $\%$.

$\mathrm{Ts}_{2}$ : required total solids of fermentation material after dilution $(8 \%)$.

\subsection{The $\mathrm{pH}$ and $\mathrm{C} / \mathrm{N}$ ratio}

The $\mathrm{pH}$ values of the fresh dung, slurry before, during and after fermentation were measured using a digital $\mathrm{pH}$ meter (Model pH-201, Taiwan) with $0-14$ of measurement range and 0.01 in resolution, as illustrated in Fig.2 (a). The $\mathrm{C} / \mathrm{N}$ ratios of the dairy cattle dung and the filling slurry were estimated by measuring the total organic carbon and total nitrogen at the analyzing laboratory of Soil Department, Faculty of Agriculture, Zagazig University, Egypt 


\subsection{The biogas composition}

A portable biogas analyzer (Multi-3gases detector, China) was used to detect and analyze the biogas volumetrically with measuring error of $\pm 10 \%$ and range of $0-100 \%$ for $\mathrm{CH}_{4}, 0-100 \%$ for $\mathrm{CO}_{2}$ and $1-1000 \mathrm{ppm}$ for $\mathrm{H}_{2} \mathrm{~S}$, as depicted in Fig.2 (b).

\subsection{The specific daily biogas yield}

The biogas daily yield in $\mathrm{m}^{3} /$ day was measured by using a gas flow meter (Model: SENSUS, Egypt) with resolution of $0.001 \mathrm{~m}^{3}$ and gas flow rate of $0.025-4 \mathrm{~m}^{3} / \mathrm{h}$. However, the specific monthly biogas yield can be determined by using Eq. 4 as follows:

Specific monthly biogas yield $=\frac{\text { Cumulative biogas yie } l d\left(\mathrm{~m}^{3} / \text { month }\right)}{T S \% \times V S \% \times \rho \times \text { Effective volume of digester }\left(3.37 \mathrm{~m}^{3}\right)},\left(\mathrm{m}^{3} / \mathrm{Kg} \quad \mathrm{vs} \cdot \mathrm{month}\right)$

Where:

- TS $\%=$ total solids for slurry.

- VS\% = volatile solids for slurry.

$-\rho=$ density of initial slurry (measured $944 \mathrm{~kg} / \mathrm{m}^{3}$ ).

\subsection{The daily gained energy}

The methane has energy value of $37.78 \mathrm{MJ} / \mathrm{m}^{3}$ (Murphy and Thamsiriroj, 2013) and consequently the daily gained energy from biogas yield was calculated using Eq. 5:

Daily gained energy = Dailybiog as yield $\left(\mathrm{m}^{3}\right) \times \mathrm{CH}_{4}(\%) \times 37.78,(\mathrm{MJ} / \mathrm{day})$
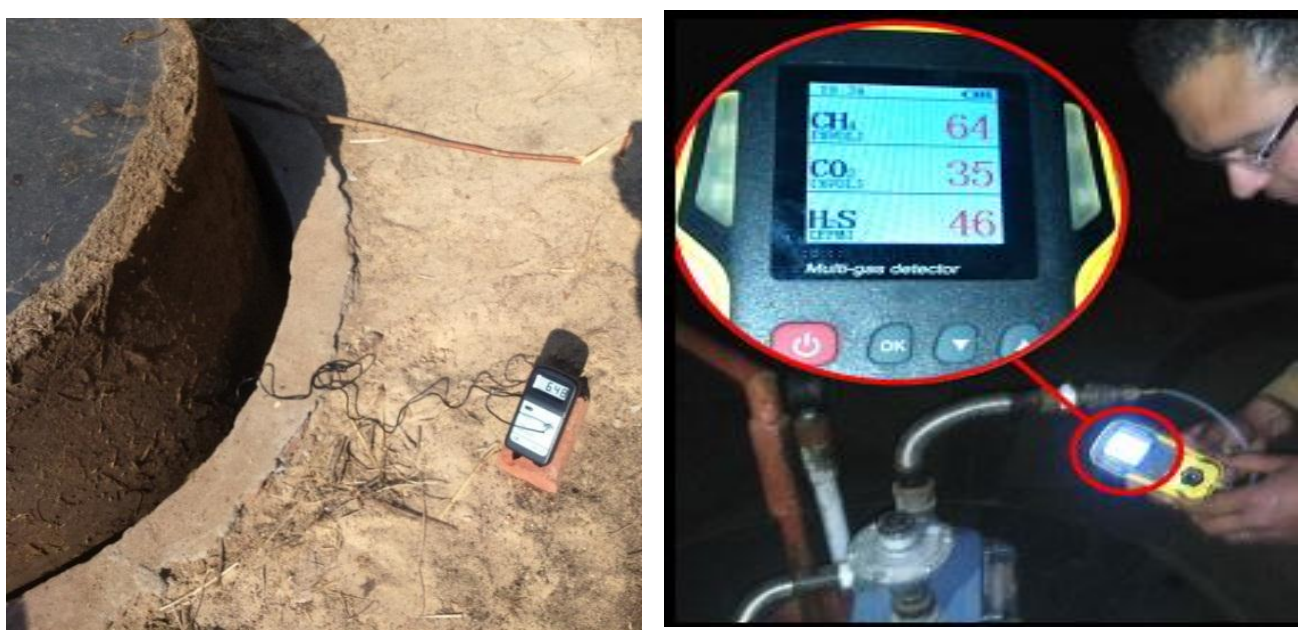

Fig. (2): Measuring devices (a) The pH meter; (b) biogas analyzer. 


\subsection{The daily required energy}

The required energy to operate the solar-heated digester the summation of the energy consumed by the hot water recirculating pump and the manual agitation during the digestion time. The daily consumed energy by the electric motor of the recirculating pump was estimated by using Eq.6:

$$
\begin{aligned}
& \text { Daily required energy (for pumps motor) } \\
& \cos \varphi \times I \times V \times 10^{-6} \times t \text {, }(\mathrm{MJ} / \mathrm{day})
\end{aligned}
$$

Besides, the daily required energy for operating the agitator manually was estimated using Eq. 7:

$$
\begin{aligned}
& \text { Daily required energy for the manual Agitation = } \\
& \mathrm{P}_{\mathrm{h}} \times 10^{-6} \times t,(\mathrm{MJ} / \text { day }) \text { (7) }
\end{aligned}
$$

Where:

I: current intensity, Ampere

$$
\mathrm{V} \text { : Voltage, }(220 \mathrm{~V})
$$

$\cos \varphi$ : power factor $=0.7$

$\mathrm{P}_{\mathrm{h}}$ : the Agitation power for human (calculated to be $70 \mathrm{~W}$ )

$\mathrm{t}$ : daily agitation time, $\mathrm{s}$ (4 times per day with total time of 30 minutes/day)

\section{8. The daily net gained energy}

The daily net gained energy was calculated using Eq. 8:

Net daily gained energy = D a ily gained en ergy-Dai ly require $d$ energy , $(\mathrm{MJ} /$ day $)$

Finally, the total gained energy (MJ/month) is the summation of daily gained energy for 30 days of the digestion time.

\section{RESULTS AND DISCUSSION}

\section{Variation of the ambient and slurry temperature for the solar- heated digester}

The temperature is a crucial factor affecting the fermentation rate of $\mathrm{AD}$ and consequently the biogas production rate. In this work, the monthly average temperature of the circulated water was $20.1^{\circ} \mathrm{C}$, in contrast the monthly average temperature of the solar hot water gained by the SSP was $68.5^{\circ} \mathrm{C}$ during the heated digestion period. According to the previous work results of the un-heated digester (Abd Allah et al., 2016); the 
average ambient temperature and slurry were $17.3^{\circ} \mathrm{C}$ and $17.9^{\circ} \mathrm{C}$, respectively. A little difference was observed in temperature values inside and outside the biogas digester, as shown in Fig.3(a). Generally, temperature inside the digester was found $0.8-2.8{ }^{\circ} \mathrm{C}$ more which is nearly equal in day, so the $\mathrm{AD}$ remained in the psychrophilic range resulting in a very low fermentation rate as well as biogas production, Concerning to the solar-heated digester, the average ambient and slurry temperatures were 21.2 and $30.2^{\circ} \mathrm{C}$, hence there is apparent difference was observed in temperature values inside and outside the biogas digester due to the integration of SSP with the digester using the solar heating loop, as illustrated in Fig. 3(b). The obtained results revealed that, the integration of SSP with the biogas digester increases the average temperature of the slurry about $9{ }^{\circ} \mathrm{C}$ over the ambient temperature and about $12.3{ }^{\circ} \mathrm{C}$ over the slurry temperature within the un-heated digester which meant that, the $\mathrm{AD}$ altered from the psychrophilic to the mesophilic range. It is evident that, the SSP integration with the digester would increase the microbial metabolism thereby the conversion of the VFA into the desired end product of biogas.
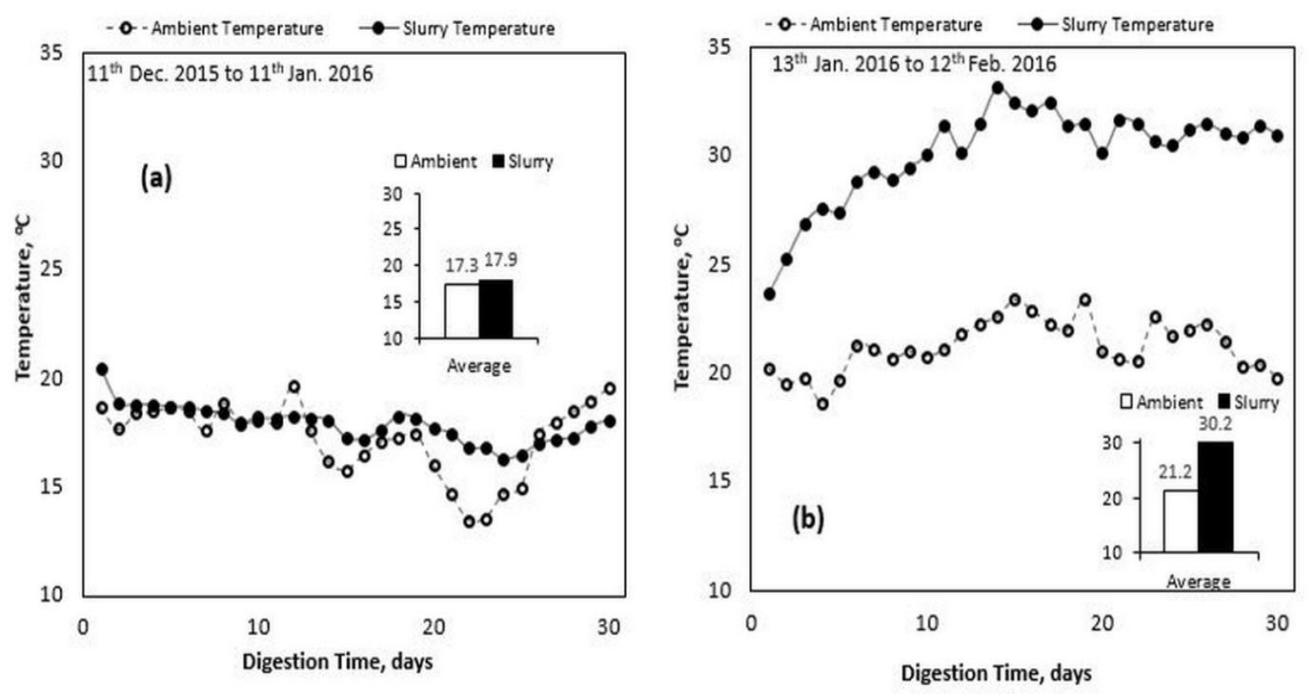

Fig. (3): Average daily variation of the ambient and slurry temperature for (a) the un-heated and (b) solar-heated digester. 


\section{Variation of influent and effluent $\mathrm{pH}$ values for the Solar-heated digester} It is well known that slurry of the anaerobic digestion needs a delicate balance between the rate of hydrolysis and methanogenesis due to of the high sensitivity of methanogenic than acidogenic to volatile fatty acids (VFA) accumulation, where the methanogenic bacteria is in thrive optimally within the $\mathrm{pH}$ range of 6.5-7.5. The $\mathrm{pH}$ variations of influent and effluent for the solar-heated and un-heated digesters during the digestion period are drawn in Fig. 4. It is clear that, the $\mathrm{pH}$ of the influent of the unheated digester decreased gradually from loading point of 7.4 to 6.8 within the first two weeks, and then it tends to be stable, simultaneously the $\mathrm{pH}$ variation of the effluent takes similar trend with higher values due to the presence of ammonia that considered a low methanogenesis. In contrast, the influent of the solar-heated digester abruptly dropped from loading point of 7.4 to 6.4 within the first five days only, as shown in Fig. 4(b).
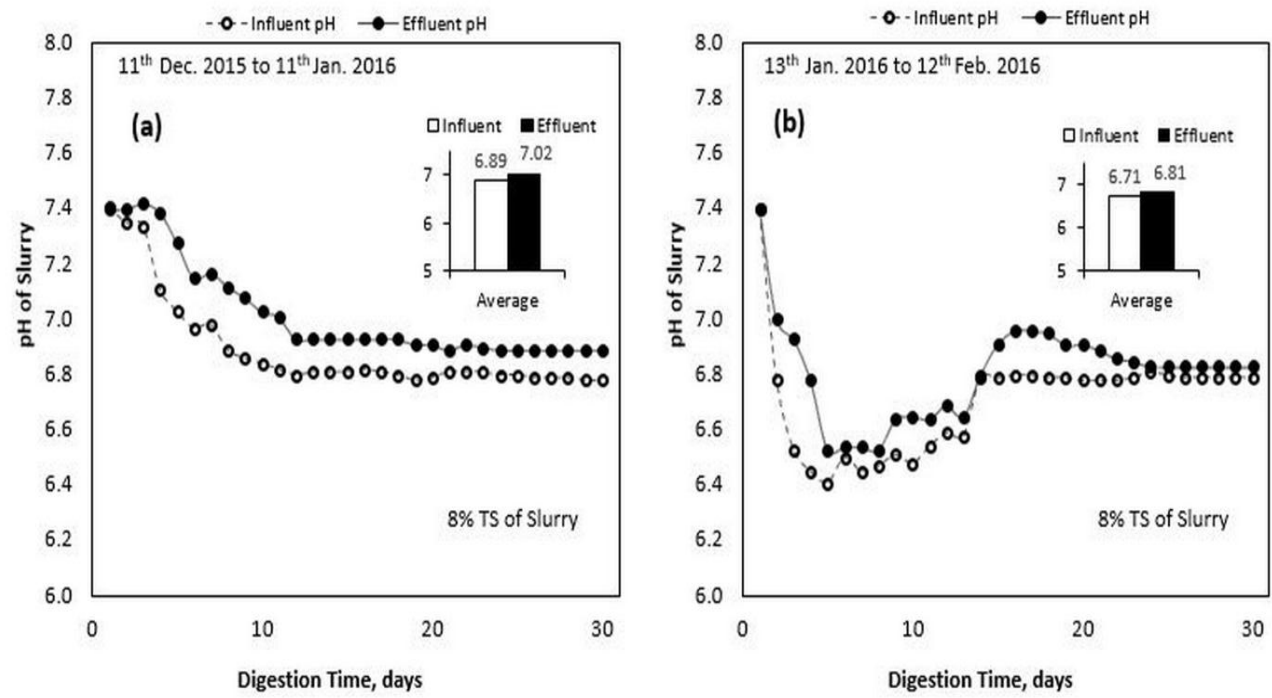

Fig.(4): Daily variations of influent and effluent $\mathrm{pH}$ values for (a) the un-heated and (b) solar-heated digester.

This could be referred to the high amount of VFA due to the rise of slurry temperature causing rapid acidification. Afterwards, the VFA were metabolized and the $\mathrm{pH}$ increased gradually to reach the peak value of 6.8 at the $13^{\text {th }}$ day, then it tends to be stable around the neutral value of 6.80 
till the end of the digestion period. This can be explained by the fact that, the slurry of cattle dung has sufficient buffering capacity producing alkalinity due to the degradation of substrates to neutralize the accumulated VFA that necessary to secure good anaerobic fermentation for enhance the biogas production. Also, the effluent $\mathrm{pH}$ values are relatively higher than the $\mathrm{pH}$ of the influent but still very close due to the good anaerobic fermentation. Generally, the average influent $\mathrm{pH}$ values were 6.89 and 6.71 , while the effluent $\mathrm{pH}$ values were 7.02 to 6.81 for the un-heated and solar-heated digester, respectively.

\section{The daily, cumulative and specific biogas yield for the un-heated and solar-heated biogas digesters}

The results of the previous investigation on the performance of the unheated digester is compared to the obtained data of the solar-heated digester taking into consideration the daily, cumulative and specific biogas yield, as depicted in Fig.5. When the average slurry and ambient temperatures were about $17.9^{\circ} \mathrm{C}$ and $17.3^{\circ} \mathrm{C}$, respectively, the average daily biogas yield for the un-heated digester increased relatively slowly from $0.061 \mathrm{~m}^{3}$ at the first day to the peak yield of $0.6 \mathrm{~m}^{3}$ at the $11^{\text {th }}$ day, then the biogas yield was decreased until the lowest yield value of $0.17 \mathrm{~m}^{3}$ at the end of the digestion time with average daily biogas yield of $0.311 \mathrm{~m}^{3}$, as shown in Fig. 5(a). It can be noticed that, there was less biogas yield during the first week of digestion that mainly due to the lag phase of microbial growth at the psychrophilic range. As to the influence of the increase the average slurry temperature up to $30.2{ }^{\circ} \mathrm{C}$ at ambient temperature of $21.2^{\circ} \mathrm{C}$ by the integration of the SSP with the biogas digester, the daily biogas yield for the solar- heated digester started from $0.370 \mathrm{~m}^{3}$ at the first day, afterwards this value increased rapidly with time to reach the maximum yield of $0.997 \mathrm{~m}^{3}$ at the $12^{\text {th }}$ day, then the biogas yield retarded gradually to about $0.612 \mathrm{~m}^{3}$ at the end of digestion month with the average daily biogas yield of about $0.711 \mathrm{~m}^{3}$, as illustrated in Fig.5(b). The cumulative biogas yield for 30 days of digestion time of both the un-heated and solar-heated digester is shown in Fig. 4. It was noticed that, the cumulative yield of biogas yield increased with rapid rate till the 
$12^{\text {th }}$ day and $14^{\text {th }}$ day for un-heated and solar-heated digester, respectively which followed by a slow rate to the end of digestion time for both digesters, as shown in Fig.5(b).

At the end of the digestion time, the total monthly cumulative biogas yields for the un-heated and solar-heated digester were 9.325 and 21.326 $\mathrm{m}^{3}$, respectively. Referred to the initially loaded TS of $8 \%$, VS of $75.6 \%$ and effective digester volume of $3.37 \mathrm{~m}^{3}$, the specific biogas yield for the un-heated and solar-heated digesters is displayed in Fig.5. The obtained results revealed that, the average monthly biogas yield of one kilogram of VS was about $0.048 \mathrm{~m}^{3} / \mathrm{kg}^{-}$vs and $0.109 \mathrm{~m}^{3} / \mathrm{kg}_{\text {-vs }}$ for both the un-heated and solar-heated digester, respectively at the day 30 of digestion. From the previous discussion, it can be concluded that the increase of average slurry temperature by about $12.3^{\circ} \mathrm{C}$ led to increase the average daily, cumulative and specific biogas yield for the solar-heated digester by about $129 \%$ more than the un-heated digester. Hence, the biogas yield increases with increases the slurry temperature by securing a stable environment of fast $\mathrm{AD}$ and consequently the biogas yield increases substantially due to exponential growth of methanogens.
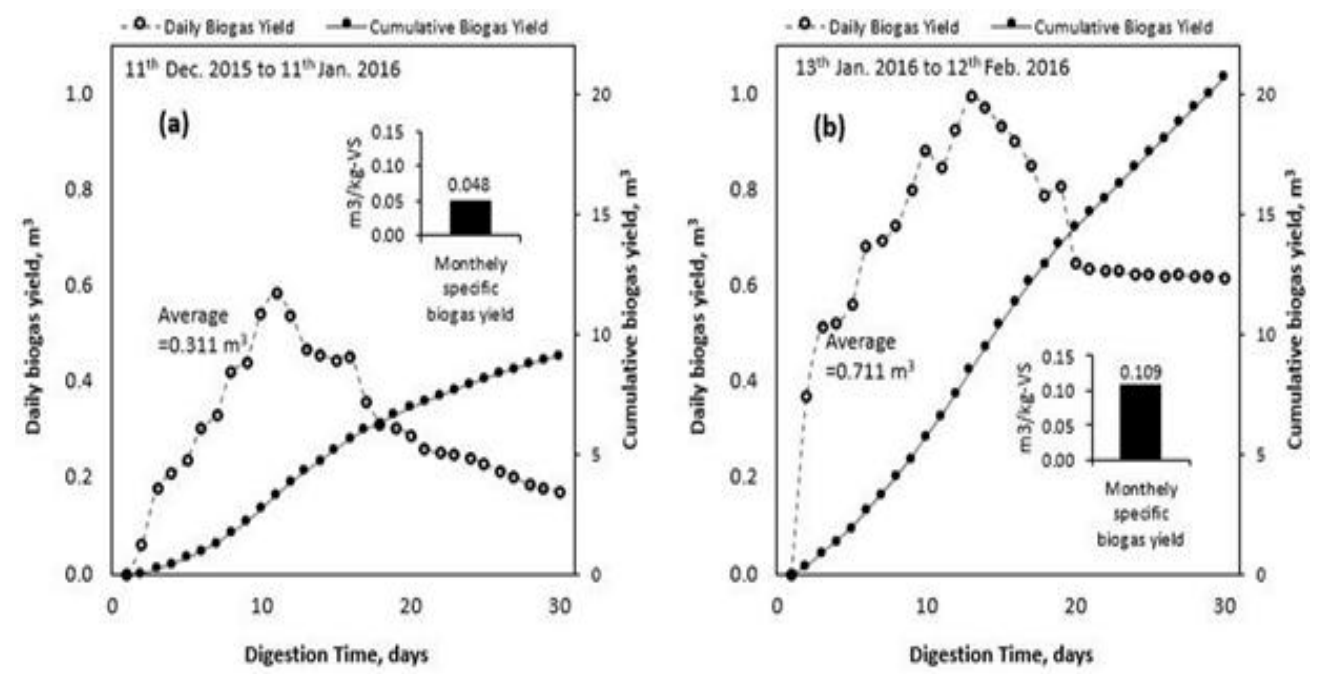

Fig. (5): Daily, specific and cumulative biogas yield for (a) the unheated and (b) solar-heated digester. 


\subsection{Biogas composition of the solar-heated digester}

As a fact, the increase of biogas yield means more methane $\left(\mathrm{CH}_{4}\right)$ will be expected that enhancing the biogas quality. In the present work, the volumetric percentage of constituted gases in the biogas mixture was determined every day during the digestion time. It is well known that, increasing $\mathrm{CH}_{4}$ content on the account of carbon dioxide $\left(\mathrm{CO}_{2}\right)$ and the other gases including the hydrogen sulphid $\left(\mathrm{H}_{2} \mathrm{~S}\right)$ in the biogas is very desirable as an important indicator of the biogas quality. The detected composition of produced biogas for the solar-heated digester during the digestion period is shown in Fig. 6. The obtained data revealed that, the $\mathrm{CH}_{4}$ content increased gradually on the first few days until the peak methane content of $79 \%$ with $\mathrm{CO}_{2}$ content of $21 \%$ and $\mathrm{H}_{2} \mathrm{~S}$ of 89 ppm at the end of first week, but after the peak period, $\mathrm{CH}_{4}$ content decreased and reached a steady percentage of $68 \%$ at last week of digestion time, simultaneously $\mathrm{CO}_{2}$ in the headspace gradually increased. The hatched areas in Fig. 6 refer to traces of other produced gases including $\mathrm{H}_{2} \mathrm{~S}$ that obtained on the first four days of start-up phase and then seems to be in a steady level till the end of experiment. According to the recorded data, the solar-heated digester yielded an average biogas composition of 70, 28 and $2 \%$ for $\mathrm{CH}_{4}, \mathrm{CO}_{2}$ and other gases including $\mathrm{H}_{2} \mathrm{~S}$, respectively.

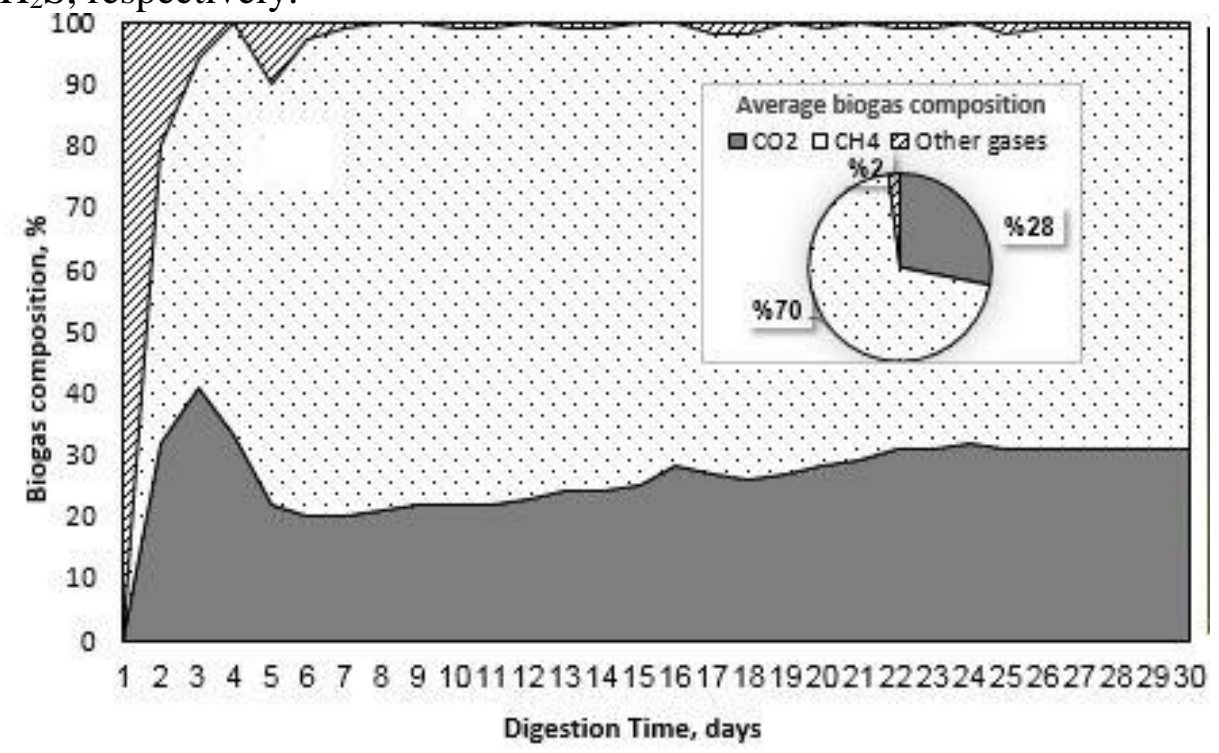

Fig.(6): The biogas composition of the solar-heated digester. 
From the previous discussion it is evident that the increase of fermentation temperature contributes in producing high biogas and methane percentage without fluctuation during the experiment.

\section{Gained energy of the solar-heated digester}

It is necessary to determine the total net gained heat energy during the experiment period to evaluate the potential of the produced energy from the solar-heated digester. Thus, the net gained energy during the experiment period had been calculated based on the daily gained and required energy to describe the net energy value at the end of digestion time, as shown in Fig. 7. Fig. 7(a) show that, the daily gained energy increased from $6.725 \mathrm{MJ}$ to the peak value of $28.259 \mathrm{MJ}$ that occurred on the $12^{\text {th }}$ day from the start of digestion period, and then it is declined to $15.716 \mathrm{MJ}$ at the end of digestion time with total gained energy of $576.3 \mathrm{MJ} / \mathrm{month}$ after 30 days of fermentation. On the other hand, the daily required energy depends on the consumed energy in the manual agitation and circulating solar hot water which was about $0.774 \mathrm{MJ} /$ day $(23.2 \mathrm{MJ} /$ month).

The data revealed that, the daily net gained energy increased from 5.95 $\mathrm{MJ}$ at the beginning of digestion period to reach its maximum value of 27.48 MJ, but it decreases to be $14.942 \mathrm{MJ}$. Hence, it obvious that the solar-heated digester can add about $553.1 \mathrm{MJ} /$ month as a total net gained energy by the end of digestion period (30 days) as depicted in Fig. 7(b).
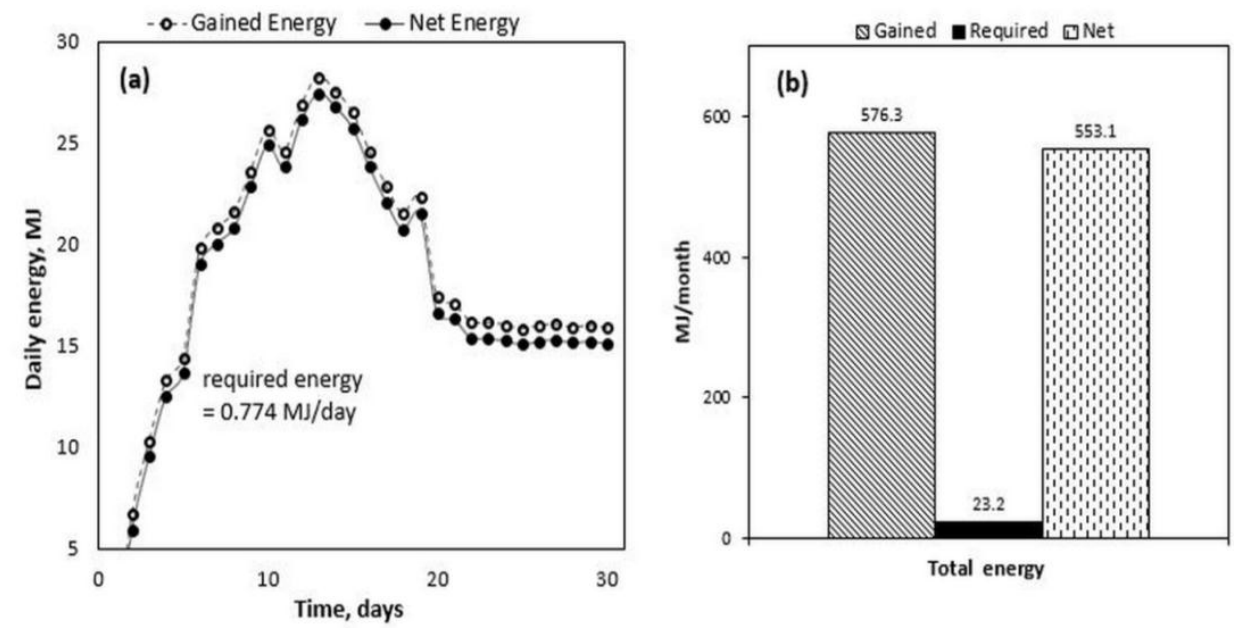

Fig.(7):Gained, required and net energy of the solar-heated biogas digester (a) daily; (b) total. 


\section{CONCLUSION}

In this work, a solar-heated pre-constructed concrete biogas digester was evaluated through the integration with a shallow solar pond (SSP) compared to the same digester without heating for 30 days of digestion time during winter season using the cattle dung ( $8 \%$ of total solids) in northern Egypt. The SSP integration with the digester increases the slurry temperature by $12.3{ }^{\circ} \mathrm{C}$ over the slurry of the un-heated digester which led to increase the average daily, cumulative and specific biogas yield by about $129 \%$ higher than the un-heated digester with total net gained energy of $553.1 \mathrm{MJ} / \mathrm{month}$.

\section{REFERENCES}

Abd Allah, W. E. (2016). Enhancing the extracted heat from the shallow solar pond to be used in biogas production. phD thesis, Fac. of Agric., Zagazig Univ., Egypt

Abd Allah, W. E., M. K. Abd El-Wahab, M. M. A. Hassan and M. A. Tawfik (2016). Study on biogas unit using dairy cattle dung during winter in Egypt. Zagazig J. of Agric. Eng., 43 (3): 10511057.

Al Seadi, T., D. Rutz , H. Prassl, M. Köttner, T. Finsterwalder, S. Volk and Janssen R.(2008). Biogas Handbook: more about anaerobic digestion (AD) . Esbjerg: University of Southern Denmark, 23 p.

Anand, R.C. and R. Singh (1993). Simple technique, charcoal coating around the digester, improves biogas production in winter. Bioresour. Technol., 45(2): 151-152.

Bansal, N. K., S. C. Bhand, S. Ram and K. K.A. Singh (1985). Study of a greenhouse concept on conventional biogas systems for enhancing biogas yield in winter months. Int. J. of Energy Res., 92(2): 119-128.

Chae, K.J., A.M. Jang, S.K. Yim and I.S. Kim ( ).The effects of digestion temperature and temperature shock on the biogas yields 
from the mesophilic anaerobic digestion of swine manure. Bioresour. Technol., 88(1):1-6.

Chenglin, M., L. Rongping and L. Xiujin (2009).Integrated system of greenhouse and solar heater for anaerobic digestion of excess activated sludge. Transactions of the Chinese Soc. of Agric. Eng., 25 (9): 210-214 (in Chinese).

Dong, F. and J. Lu (2013). Using solar energy to enhance Biogas production from livestock residue - A case study of the Tongren Biogas engineering pig farm in South China. Energy, 57: 759-765.

El-Mashad, H.M., W. K. van Loon, G. Zeeman, G.P. Bo and G. Lettinga (2004). Design of a solar thermophilic anaerobic reactor for small farms. Biosys. Eng., 87(3): 345-353.

El-Sebaii, A. A. (2005). Thermal performance of a shallow solar-pond integrated with a baffle plate. Appl. Energy, 81(1): 33-53.

FAO (2013) Production year book. The United Nations, http://faostat3.fao.org/browse/Q/QA/E

Ganesh, S. and S. Arumugam (2016). Performance study of a laboratory model shallow solar pond with and without single transparent glass cover for solar thermal energy conversion applications. Ecotoxicol and Environ Safety, 134:462-466.

Gupta, R.A., S.N. Rai and G.N. Tiwari (1988).An improved solar assisted biogas plant (Fixed dome digester): A transient analysis. Energy Convs and Manag., 1988; 28(1):53-57.

Jiao, Y. Z., P. F. Li, G. Li, Q. G. Zhang, P. Ding, S. P. Wang, Z. Gao, S. Du and C. He (2016). Design and preliminary experimental research on a new biogas fermentation system by solar heat pipe heating. Int. J. Agric. \& Biol. Eng., 9(2): 153-162.

Kitamura, Y., P. Dan, L. Gautz and T. Liang (2007). A rotational hot gas heating system for bioreaetors. Biosys. Eng., 98(2): 215-223. 
Kumar, K. V. and R. K. Bai (2008). Solar greenhouse assisted biogas plant in hilly region - A field study. Sol. Energy, 82 (10): 911917.

Kumar, K. V. and R. K. Bai (2005). Plastic biodigesters - a systematic study. Energy For Sust. Develop., 9(4): 40-49.

Li, J. Y., J. Li , Q. Y. Liu and H. Zheng (2014). Design of the solar energy-heated biogas digester. Adv. Mater. Res., 953-954:103-106.

Lu, Y., Y. Tian, H. Lu, L. Wu and X. Li (2014). Study of solar heated biogas fermentation system with a phase change thermal storage device. Appl. Therm. Eng., 88: 418- 424.

Murphy, J. D. and T. Thamsiriroj (2013). Fundamental science and engineering of the anaerobic digestion process for biogas production. In: Wellinger A, Murphy J, Baxter D. (Ed.), editors. The biogas handbook: science, production and applications. Cambridge: Woodhead Publishing Ltd., pp. 104-130.

Nijaguna, B.T. (2009). Biogas technology. New Delhi: New Age International (P) Ltd.47 p.

Santosh, Y., T.R. Sreekrishnan, S. Kohli and V. Rana (2004). Enhancement of biogas production from solid substrates using different techniques-a review. Bioresour. Technol., 95(1): 1-10.

Shi, H. X., K. Xu and T. Lv (2013). Heating systems combined with solar energy and lake water source for biogas digester. Appl. Mech. and Mater, 291: 1684-1689.

Subramanyam, S.(1989). Use of solar heat to upgrade biogas plant performance. Energ. Convs and Manag., 29(1): 73-75.

Wang, L., B.N. Zhu, H.R. Yuan, Y.P. Liu, D.X. Zou and X. J Li (2016).Comparative investigations on pilot-scale anaerobic digestion of food waste at $30^{\circ} \mathrm{C}$ and $35^{\circ} \mathrm{C}$. Int. J. Agric. and Biol. Eng., 9(1): 109-1187. 
Xu, Z., H. Wu and M. Wu (2010). Energy performance and consumption for biogas heat pump air conditioner. Energy, 35(12): 5497-5502.

Zeeman, G. and G. Lettinga (1999). The role of anaerobic digestion in closing the water and nutrient cycle at community level. Water Sci. Technol., 39(5):187-194.

Zhong, Y., M. B. Roma , Y. Zhong, S. Archer, R. Chen, L. Deitz, D. Hochhalter, K. Balaze, M. Sperry, E. Werner and D. Kirk (2015). Using anaerobic digestion of organic wastes to biochemically store solar thermal energy. Energy, 83: 638-646.

Zhu, X. H., C. Zhong and Z. B. Jiang (2013). Solar biogas digester and wetland-pond system for rural wastewater treatment. Adv. Mater. Res., 800: 610-613.

\section{الملخص العربي}

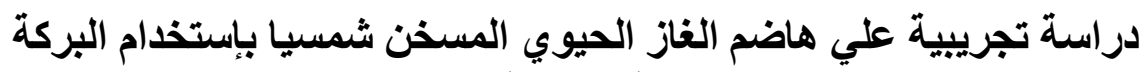
الشمسية الضحلة في المناخ البارد المن فئي

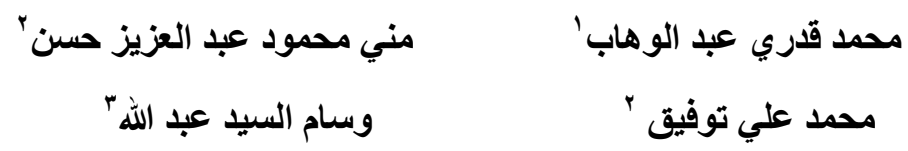

في شمال مصر درجة الحرارة غالبًا أقل من • ب درجة مئوية خلال شهور الثتاء و التي تعتبر

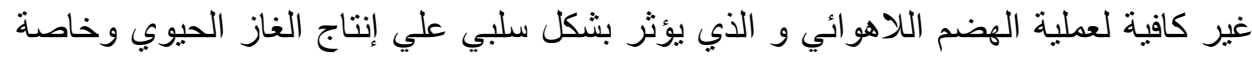

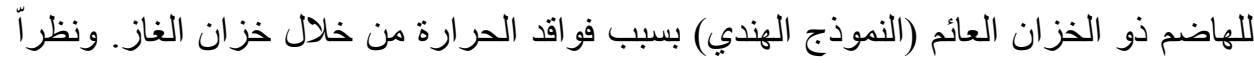

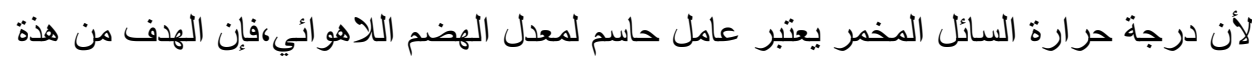

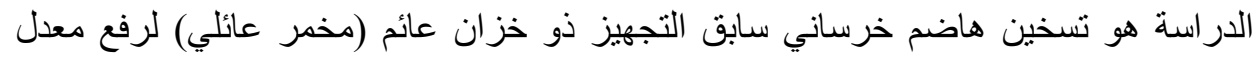

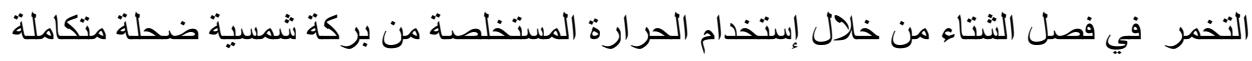

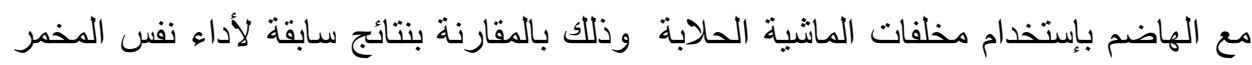
بدون تسخين.

$$
\begin{aligned}
& \text { ' أستاذ الهندسة الزراعية المتفرغ - كلية الزراعة ـ جامعة الزقازيق - مصر. }
\end{aligned}
$$

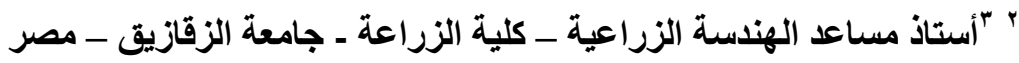

$$
\begin{aligned}
& \text { " مدرس الهندسة الزراعية ـ كلية الزراعة ـ جامعة الزقازيق - مصر. }
\end{aligned}
$$


تم تقييم أداء الهاضم المسخن شمسياً تحت نفس ظروف التشغيل للهاضم بدون تسخين بإستثناء

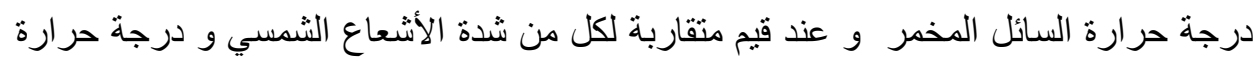

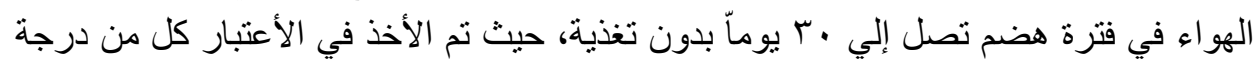

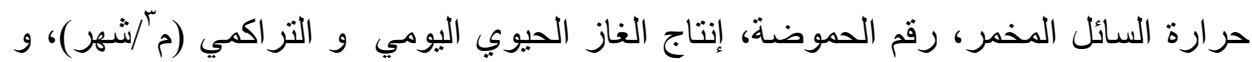

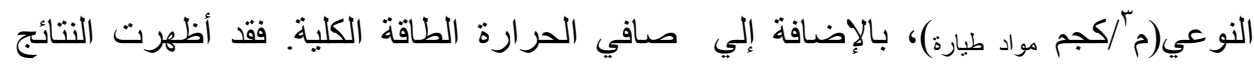

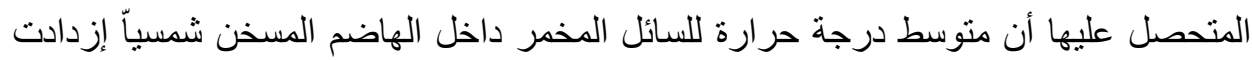

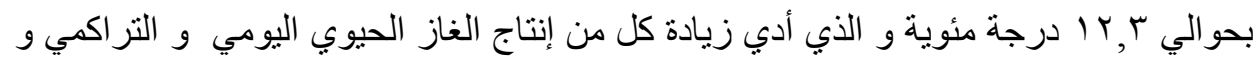

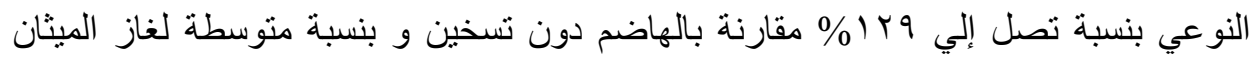

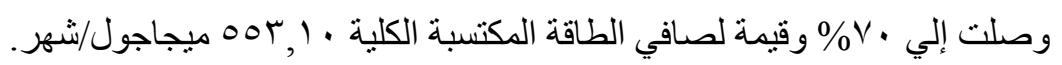

